\section{Foreign Student Travel Grants for APSA Annual Meeting}

Each year the American Political Science Association awards travel grants to advanced, foreign graduate students enrolled in American universities to enable these students to attend the APSA's annual meeting. Grants will be funded by the Asia Foundation, the Huang Hsing Foundation (USA) and other sources including the APSA.

Monies from the Asia Foundation are awarded to students from Asian countries while graduate students from other nations are being funded through the Huang Hsing Foundation and the APSA.

The APSA selects recipients on the basis of the following guidelines:

- Recipients of awards must be studying in the U.S. at the time the award is offered to them.

- Recipients must be full-time graduate students at U.S. institutions of higher learning. Foreign graduate students in refugee, immigrant, or tourist visa status are not elgible.

- Recipients are not eligible for awards if they are receiving any U.S. government funds, for either academic or travel expenses.

- Recipients may not have received a grant previously.

The maximum amount that can be awarded to any individual is $\$ 300$.

Applicants must complete a form available from the APSA's national office and must have their departmental chairpersons write a letter of support of their applications. The deadline for receipt of applications for a travel grant to the September 2-5, 1993 Annual Meeting in Washington is June 15. Application forms and further information are available by writing: Foreign Advanced Graduate Student Travel Grants, APSA, 1527 New Hampshire Ave., NW, Washington, DC 20036.

\section{Annual Meeting Short Courses}

Each year in conjunction with the APSA Annual Meeting the Association and APSA Organized Sections offer a selection of short courses. The courses provide an opportunity for members to enhance their knowledge about a field and to reinvigorate their teaching and research. The 1993 short course selection is described below.

Short courses are scheduled for the day before the Annual Meeting on Wednesday, September 1. A registration form with complete times, costs and descriptions is located in the back of this issue of $P S$ along with the preliminary program for the 1993 Annual Meeting. Preregistration by July 30 is strongly encouraged to ensure that appropriate course materials and reservations are prepared for you.

\section{Short Course 1: The Changing Ideology of Parties}

The end of the Cold War has stimulated a re-examination of the assumptions that have guided the American polity since the conclusion of World War II. This year's Organized Section on Political Organizations and Parties APSA workshop focuses on the intellectual challenges facing the Democratic and Republican Parties. We will examine those challenges from several vantage points: the relationship between citizens and parties, how the majority party organizations view their intellectual challenges, how the parties can redefine themselves in ways that may have significant electoral appeal, and how voters presently assess the parties respective capabilities and directions.

Participants in the workshop include leading academic scholars, pollsters, and practitioners from the political parties and the media. The workshop will be held on Wednesday at $10 \mathrm{a} . \mathrm{m}$. at the Washington Hilton and conclude by 4 p.m. (More details are provided on the registration form in the back of $P S$.)

\section{Short Course 2:}

The Turn to History in the Study of American Politics

The study of American politics has become more historical in recent years. Scholars with a variety of substantive concerns have turned to America's past for a new angle of vision on the present. This workshop, sponsored by the APSA Organized Section on History and Politics, will explore the new uses of history in this field and the potential for theoretical advance. (Registration information is provided in the back of $P S$.)

\section{Short Course 3:}

\section{Interactive Video in Political Science}

The convergence of video and computer technology has led to the development of interactive video. Interactive video uses either a personal computer or a Macintosh to control a laser video disk so that you have random access to the various video clips and stills on the disk. This multimedia technology allows the computer to be useful in teaching value oriented, as well as behavioral oriented courses.

The full-day workshop on interactive video will be led by Marc Triebwasser of Central Connecticut State University. The workshop sponsored by the APSA Organized Section on Computers and Multimedia will include: a general introduction to interactive video disks for the beginner; how interactive video can be used in teaching; a survey of available interactive video disks and other video materials in political science; how you can create your own interactive video disks on campus; the prospects for digital video and CD-ROMs; and sources for video clips on disks and on VCR tapes.

Lab sessions will be conducted so that participants can gain hands-on experience. No prior knowledge of computers or video technology is required.

Because of the equipment needs for the hands-on portion of the workshop, it is important to register as soon as possible. No same day registration will be possible. (Registration details are in the back of this issue of $P S$.)

\section{Short Course 4: Teaching About Security in a Changing World}

The International Security and Arms Control Section is sponsoring a short course entitled "Teaching About Security in a Changing World." The full-day course will run 
from 9:30 a.m. to 4:30 p.m. on Wednesday, September 1.

In a world that is dynamic, teaching about security issues is a challenge that many of us confront. The traditional notions of security are changing, and materials often seem to be out-of-date as soon as they are published. The dominance of the military as the primary instrument of national might and power is being eclipsed by the role of economics. Military force is being used as an instrument delivering humanitarian aid and relief. After more than 45 years, the United Nations is emerging as a dominant, and viable, multinational force. Given these and other changes, "security" must now be broadly defined to include a range of issues and policy decisions far greater than the narrow approaches used in the traditional international relations literature.

Those of us in the field of international relations, foreign policy, and security studies are confronting the dilemma of how to present this material to our students as we face the changing global situation. There is a need to balance the traditional theoretical approaches with the ability to understand the realities of the present day.

This course will address some of those concerns and offer insights into teaching about security in a changing world. We will begin in the morning with a lecture. Participants in the course will be given samples of syllabi used by various faculty members in different institutions to teach this topic. These approaches will be compared and discussed as part of the morning session.

Following lunch at the Washington Hilton, we will spend the afternoon at the Pentagon for a tour of the building, and meeting with one or two officials there who serve in a decision-making capacity. We hope to get their insights into what the changing definition of security means for U.S. policy. (Registration details are in the back of this issue of $P S$.)

\section{Short Course 5: \\ Game Theory, Case Studies, and International Relations}

With the advent of the Pew Case Studies in International Affairs (now more than 150 cases of international negotiations on security and political economy issues), international relations specialists would seem to have ample raw material on which to test their ideas and theoretical notions. The problem is that the "facts" in these cases do not always speak for themselves, nor are they comparable. Although these cases may well serve their avowed pedagogical purpose"to stimulate interaction and discussion in the classroom" - they do not contribute to theory building and may, ironically, give students little to take beyond the classroom as they quickly forget the facts.

By the same token, a once-overlightly treatment of Prisoners' Dilemma, Chicken, or Stag Hunt in the classroom hardly persuades students that game theory can provide them with an in-depth understanding of major strategic issues in international relations. What is needed is a relevant kind of game theory that can take the raw material of factually based cases, place it within a rigorous theoretical structure, and thereby test theory against reality-or at least provide some explanation of the choices made by decision makers in these cases.

Steven J. Brams has attempted to develop such a game-theoretic structure in Theory on Moves (Cambridge University Press, forthcoming), whose framework is:

- dynamic-choices are not made de novo but have a history that affects future play;

- look-ahead-players try to anticipate the consequences of future moves and countermoves;

- ordinal-players can rank outcomes but not necessarily assign utilities to them;

- power based-players have different capabilities to threaten each other, to determine the order of moves, or to hold out longer;

- information dependent-players do not share the same information, allowing for misperceptions and deceptions.

In the short course the theory of moves will be applied to several cases of international conflict and negotiation, including the Cuban missile crisis, bombing campaigns in Vietnam, the Iran hostage crisis, the
Uruguay round of the GATT negotiations, and examples of magnanimous and nonmagnanimous behavior of victors toward defeated parties after wars. No prior knowledge of game theory is assumed. The price of the course (\$25) includes a copy of Theory of Moves, which will be sent in advance to participants. (Additional registration information is available in the back of $P S$.)

\section{Short Course 6: \\ The Clinton Administration and the Prospects for Reinventing Federalism}

Join policy experts and Clinton administration representatives for an exciting and informative afternoon of briefings at the U.S. Advisory Commission on Intergovernmental Relations (ACIR) on the federalism policy initiatives of the Clinton Administration. The short course sponsored by the APSA Organized Section on Federalism and Intergovernmental Relations will address the following question: How do new presidential administrations formulate and implement their federalism policy agenda and intergovernmental strategies? How does the first year of the Clinton administration compare with earlier administrations in terms of the formulation of its federalism agenda and the philosophical and practical considerations on which that agenda is based? (Former governors have occupied the White House for twelve of the past sixteen years.) What are the most significant areas to watch for the continuities and discontinuities between the Reagan-Bush and Clinton years in restructuring the intergovernmental system of federal assistance, regulation, and preemption? How are the answers to these questions affecting early steps by the Clinton Administration to pursue some of the following policy "mandates for change": rebuilding the economy; reducing the federal deficit; investing in the nation's infrastructure; providing affordable, universal health care; reforming the welfare system; educating America; and greening the market?

The short course will be limited in numbers and will be held at the new offices of the U.S. Advisory Commission on Intergovernmental Relations (ACIR). (Registration informa- 
tion can be found in the back of this issue of $P S$.)

\section{Short Course 7: \\ Politics and the Life Sciences: \\ Methods Workshop}

The Association for Politics and the Life Sciences will offer a workshop of methods. The half-day seminar ( 2 p.m. to $4: 30$ p.m.) will be directed by James N. Schubert of Northern Illinois University and Roger D. Masters of Dartmouth College. There is a $\$ 25$ charge for participants. (Registration details are in the back of this issue of PS.)

\section{Short Course 8: \\ Pre-Law Advising and the Political Scientist}

This is a short course designed to improve the skills of political scientists who find themelves responsible for pre-law advising. The sessions will examine the steps necessary to establish a successful pre-law program. Topics to be addressed will include: Getting Started: Identifying Students and Security Resources; the Application Process; LSAT and LSAS: What the Letters Mean; Preparing for the LSAT: the Commercials and Do-It-Yourself; Ranking the Law Schools: Finding the "Right" Law School for Your Students; Financial Aid Opportunities in the Nineties; Life After Law School?; and the Role of Pre-Law Associations.

The course will be divided into a morning and afternoon session. The morning session will run from 10 a.m. to noon; the afternoon session from 2 p.m. to 4 p.m.

Course coordinator will be Francis Graham Lee of St. Joseph's University. Working with Dr. Lee will be: Argot Baker (Southern Methodist University), Leo J. Flynn (Pomona College), Jack Fruchtman (Towson State University), Frank X. J. Homer (University of Scranton), Beth Cobb O'Neil (Law School Admissions Services), Jerry Polibard (University of Texas Pan American), Don Racheter (Central University), and Gerald Wilson (Duke University). Each of the course leaders has been involved as officers in either their regional pre-law associations or the Pre-Law Advisers National Coordinating Council.

The cost of registration for the course is $\$ 25$. Participants will receive copies of the $S A P L A$ Guide for Pre Law Advisers, the MAPLA Survey of Law Schools, The Official Guide to U.S. Law Schools, and LSAT test information packets. (Registration information is available in the back of PS.)

\section{Short Course 9: \\ Using and Abusing Data in the Study of Law and Courts: A Hands-On Demonstration and Discussion}

The Law and Courts Section of the APSA will hold a short course at 1 p.m. on Wednesday on using and abusing data in the study of law and courts. The short course will be in two parts. The first half will provide a hands-on demonstration of existing U.S. Supreme Court databases, including the United States Supreme Court Judicial Database (ICPSR 9422) and a newly-compiled one, which integrates the Judicial Database with information on amicus curiae participants, parties, and values and opinions. Participants can expect to learn about the contents of the databases and how to use them for research and classroom purposes.

The second part of the short course will consist of two roundtable discussions on (1) the assets and deficits of the existing databases and (2) the application of data-based approaches to the study of courts and law. Lawrence Baum, John Brigham, Lee Epstein, James Gibson, Leslie Goldstein, Joel Grossman, Ronald Kahn, and Harold Spaeth among others will facilitate discussion. The Section hopes that graduate students and faculty alike will participate.

Registration details are to be found in the back of this issue of PS.

\section{Short Course 10: Personality and Political Behavior}

This course sponsored by the APSA Organized Section on Political Psychology is designed to survey the field of personality and politics. After considering the political circumstances under which leader per- sonality is most apt to come into play, this course will examine the psychological tie between the leader and his followers, analyzing the psychological basis of charismatic leader/follower relationships. Course content will focus on: (1) the effects of the life cycle on political behavior; (2) the effects of age, ill health and disability on leadership decision making and inner circle dynamics; (3) the psychology of political terrorism; (4) the paranoid political actor; and (5) individual and group psychology of crisis decision making. The topics will be illustrated with historical cases. Among the examples drawn upon will be Hitler, Gandhi, Stalin, Woodrow Wilson, and the Cuban Missile Crisis. The course will be led by Jerrold M. Post, M.D., of George Washington University. (Additional registration information is available in the back of PS.)

\section{Short Course 11: Leading Scholar Series}

This year Richard F. Fenno, Jr. of the University of Rochester will continue the Leading Scholar series. The series is exclusively for graduate students and will focus on topics relating to professional life as a political scientist. More details are provided on the registration form in the back of this issue of $P S$.

\section{Verba Nominated President-Elect}

The 1993 Nominating Committee, composed of Michael Preston, University of Southern California, chair; Joseph Cooper, Johns Hopkins University; Robert Bates, Duke University; Ellen Frankel Paul, Bowling Green State University; Gary Orfield, Harvard University; and Donna Bahry, University of California, Davis, propose the following slate for Association officers and Council members. 